\title{
Water Quality at the Habitat of the Podostemaceae in Ghana
}

\author{
G. K. Ameka ${ }^{1 *}$, K. A. A. de Graft-Johnson ${ }^{2}$ and J. K. Adomako ${ }^{1}$ \\ ${ }^{\prime}$ Department of Botany, University of Ghana, P. O. Box LG 55, Legon, Ghana \\ ${ }^{2}$ CSIR-Water Research Institute, P. O. Box AH 38, Achimota, Ghana \\ *Corresponding author
}

\begin{abstract}
The water quality and river catchment characteristics of Ankasa, Asuboni and Pawnpawn rivers in Ghana where Podostemaceae grow were determined using standard methods. The altitude of the sites ranged from 100 to $290 \mathrm{~m}$ above sea level. The catchment areas for the sites vary from 35 to $171 \mathrm{~km}^{2}$. Between $10-81 \%$ of the catchment areas of the sites are within forest reserves. The study showed that the Podostemaceae in Ghana inhabit rivers with the following range of physico-chemical characteristics: $p \mathrm{H}$ 6.7-7.3, calcium 2.2-16.0 $\mu \mathrm{g} \mathrm{l-1}$, ammonia-nitrogen $0.07-0.90 \mathrm{mg} \mathrm{1-1}$, chloride $6.8-38.0 \mathrm{mg} \mathrm{l}^{-1}$, electrical

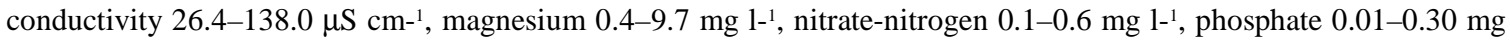
$1^{-1}$, silicate $0-21.4 \mathrm{mg} \mathrm{l}^{1-1}$ and sulphate $1.5-20.8 \mathrm{mg} \mathrm{1-1}$. The results indicate the quality of water at the habitat of Podostemaceae in Ghana.
\end{abstract}

\section{Introduction}

The family Podostemaceae is one of the most remarkable freshwater herbaceous flowering plant families. This unique family consists of haptophytic and rheophytic plants (van Steenis, 1981; Cook, 1996) generally referred to as 'river-weeds'. They occur usually in tropical and subtropical regions and occasionally in temperate regions, e.g. Podostemum ceratophyllum Michx. occurs in temperate North America (Philbrick \& Crow, 1983) and Cladopus austro-osumiensis Kadono \& Usui in Japan (Kadono \& Usui, 1995). The c. 269 species in c.50 genera of the family occur in the Neotropics and Old World (Ameka, 2000). They grow in fast flowing streams and rivers, and plummeting waterfalls, with distinct seasons of high and low flow regimes. Vegetative growth occurs during high water level and flow in the rainy season, and flower and fruit production occur during low water level and flow in the dry season. While many Podostemaceae species are annuals, others are perennials.

Podostemaceae are usually the most significant macrophytes in tropical rivers and play very important roles in tropical river ecology. They are involved in primary production contributing to autochthonous carbon (Quiroz et al., 1997), and are important food source for aquatic herbivores (Gessner \& Hammer, 1962). They are also involved in nutrients uptake and release. Their eventual use by detritus feeders is also important. They also act as substrata for diverse assemblage of epiphytic microscopic flora as well as habitat for aquatic fauna.

Sioli (1986) has stated that rivers are the most polluted among tropical aquatic ecosystems. This is because rivers receive more pollutants as the human population and development needs increase. In recent years there has been an increase in land use in the catchment areas of tropical rivers, e.g. for farming, roads, logging, mining, etc. resulting in the introduction of pollutants from industries, agro-chemicals and mine effluents into some of the rivers. This threatens the habitats of Podostemaceae and other river biota. Philbrick \& Crow (1983), Philbrick \& Novelo (1995) and Novelo \& Philbrick (1997) have reported on the possible loss of Podostemaceae species in North America (USA and Mexico) due to human impacts on the rivers in which the species are found. Cross Bell (1990) has provided evidence that the disappearance of three Podostemaceae species down stream of a rubber factory in India was due to acid discharge from the factory into the river. Such anthropogenic impacts on the survival of Podostemaceae indicate the need to conserve and protect the habitats of the species.

Data on water quality at the sites where Podostemaceae occur are scanty except for work done, e.g. by Grubert (1975) in South America, Noro et al. (1994) in Japan and Quiroz et al. (1997) in 
Mexico. It is important that baseline data on water quality where Podostemaceae grow are gathered so that the extent of changes in the future, particularly through anthropogenic activities could be assessed and corrective measures taken before the change reaches the threshold. This is important because many of the Podostemaceae species occur in single rivers or small geographical areas (Cook, 1996; Ameka et al., 2002), and the destruction of their habitats can lead to total loss of the species. This paper is a contribution to efforts at providing data on water quality at the habitat of the Podostemaceae family and draws attention to the threats posed by human activities to the sites where the Podostemaceae thrive. The water quality at the habitats of three Podostemaceae species, namely Lederman-niella bowlingii (J. B. Hall) C. Cusset, Saxicolella amicorum J. B. Hall, and Tristicha trifaria (Bory ex Willd.) Sprengel occurring in Ghana is presented in this paper.

\section{Materials and methods}

River-rapids on the Asuboni, Ankasa and Pawnpawn rivers in southern Ghana (Fig. 1), where the three Podostemaceae species Ledermanniella bowlingii, Saxicolella amicorum and Tristicha trifaria, respectively, grow were sampled once a month from January 1997 to December 1998 to determine the water quality of the habitats of the species. For each species, water samples were collected from one particular point in the river throughout the period of study for physicochemical analysis. This point was used as reference in determining the catchment area of the river.

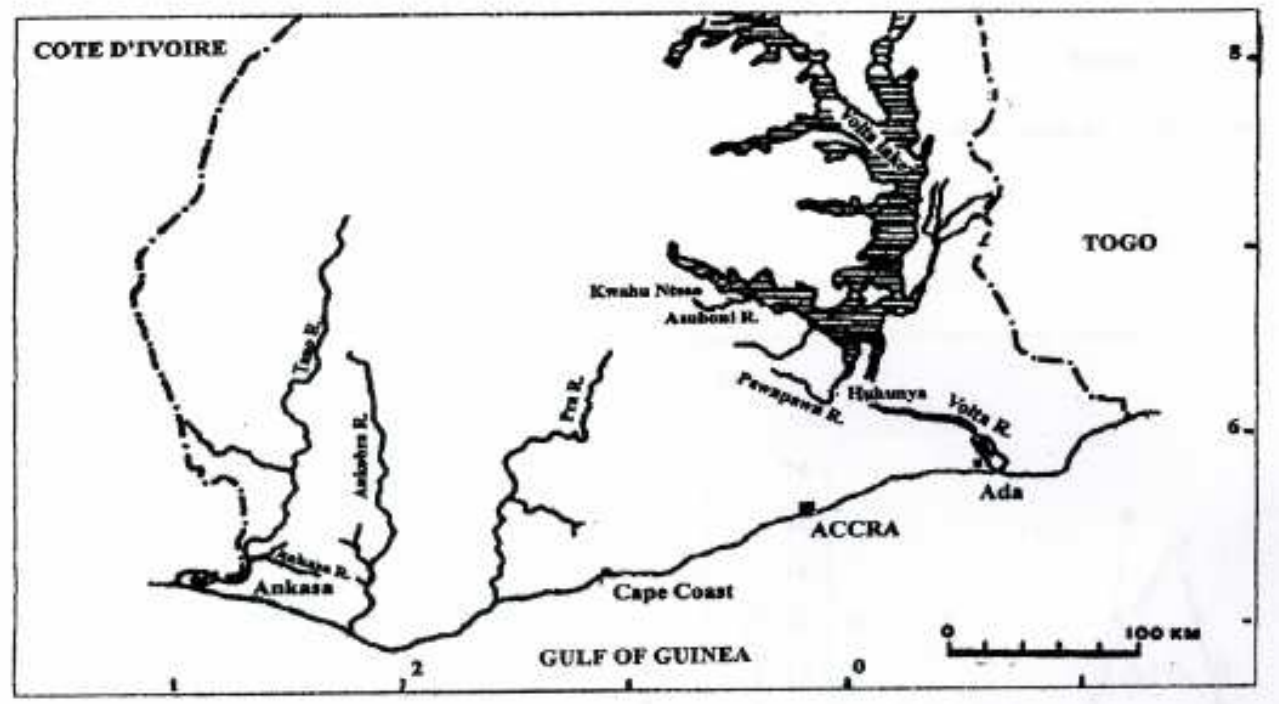

Fig. 1. Asuboni, Ankasa and Pawnpawn rivers in southern Ghana where Podostemaceae were found and water quality determined

The water samples were collected in $250 \mathrm{ml}$ pre-washed and labelled polypropylene bottles. The bottles were washed three times in tap water and finally rinsed in distilled water. The sample bottles were again rinsed three times with the river water before sample taking. Samples were taken by filling the bottles to the top to exclude air. The bottle lids were also washed in the water and screwed on while the bottles were still submerged. Care was taken not to disturb the riverbed near the point of sampling and this was achieved by positioning the bottle fairly upstream from the spot in the water where the collector was standing.

Hydrogen ion concentration $(p \mathrm{H})$ was measured using a Jenway $3071 p \mathrm{H}$ meter and the electrical conductivity was determined with a Jenway 4071 Conduc-tivity meter in the field. The 
water samples, other than those for determination of $p \mathrm{H}$ and electrical conductivity, were stored on ice and transported to the laboratory where they were kept in a refrigerator at $4{ }^{\circ} \mathrm{C}$ and analysed.

Twelve parameters including ammonia-nitrogen, calcium, chloride, magnesium, nitratenitrogen, phosphate, silicate and sulphate content, total dissolved solids, total hardness, total suspended solids and turbidity were determined according to the relevant standard methods cited in Table 1. The following characteristic features at the sites were also recorded:

TABLE 1

Methods used for river water analysis. Unless otherwise stated the methods used are as described in APHA-AWWAWPCF (1989)

Parameter Method

\begin{tabular}{ll} 
Orthophosphate $\left(\mathrm{PO}_{4}-\mathrm{P}\right)$ & Reaction with molybdate (Mackereth et al., 1978) \\
Chloride $\left(\mathrm{Cl}^{-}\right)$ & Silver nitrate titration with potassium dichromate \\
Sulphate $\left(\mathrm{SO}^{2-}{ }_{4}\right)$ & Turbidimetric using barium chloride \\
Silicate $\left(\mathrm{SiO}_{4}\right)$ & Molybdosilicate method \\
Calcium $\left(\mathrm{Ca}^{2+}\right)$ and total hardness & Titration with ethylenediamine tetraacetic acid \\
Magnesium $\left(\mathrm{Mg}^{2+}\right)$ & Calculated as $\mathrm{mg} \mathrm{l}^{-1} \mathrm{Mg}=\left(\right.$ total hardness $\left.-\mathrm{Ca}^{2+}\right) \times 0.244$ \\
Ammonia-nitrogen $\left(\mathrm{NH}_{3}-\mathrm{N}\right)$ & Indophenol blue method $(\mathrm{FAO}, 1975)$ \\
Nitrate-nitrogen $\left(\mathrm{NO}_{3}-\mathrm{N}\right)$ & Hydrazine reduction, followed by diazotizing to form an Azo dye \\
Turbidity & Nephelometric method \\
Total suspended solids & As non-filterable residue dried at $105{ }^{\circ} \mathrm{C}, \mathrm{mg} \mathrm{l}^{-1}$ \\
\multicolumn{1}{c}{ Total dissolved solids } & As filterable residue dried at $180{ }^{\circ} \mathrm{C}$, mg li $l^{-1}$
\end{tabular}

1. The geographical co-ordinates of the sites using a Global Position System, Garmin GPS 45, set to read in degrees and minutes.

2. The altitude (height above sea level) using THOMMEN TX altimeter.

3. Rock types identified in permanent mounts of $3 \mathrm{~mm}$-thick rock sections examined under a Nikon HFX Scientific microscope.

4. The Forest type according to the classification of Hall \& Swaine (1981).

5. Relevant rainfall data provided by the Ghana Meteorological Services Depart-ment and Ameka (2000).

6 River catchment characteristics accord-ing to geological survey maps of the Survey Department of Ghana (Anon., 1973).

\section{Study area}

The altitude and geographical co-ordinates of the study area are shown in Table 2. The riverbed in Ankasa river at the site where $S$. amicorum grows consists of solid rock, boulders and rocks of various sizes. The rock is composed of $100 \%$ quartz vein and it is of the Lower Birimian formation. At the site in Asuboni river where L. bowlingii grows, the riverbed is also made up of 
solid rock and rocks of various sizes while in the Pawnpawn river where T. trifaria occurs the riverbed is of solid rock. The rocks of the Asuboni and Pawnpawn riverbeds are composed of almost 100\% quartz and are part of the Obosum sandstone of the Voltaian formation.

TABLE 2

Geographical position and altitude, in metres above sea level, of the study sites

\begin{tabular}{|c|c|c|c|c|}
\hline Locality & River & Latitude, $N$ & Longitude, $W$ & Altitude (m) \\
\hline Ankasa & Ankasa & $5^{0} 13.50$ & $2^{0} 39.12$ & 100 \\
\hline Kwahu Nteso & Asuboni & $6^{0} 45.00$ & $0^{0} 35.52$ & 290 \\
\hline Huhunya & Pawnpawn & $6^{0} 11.34$ & $0^{0} 12.91$ & 275 \\
\hline
\end{tabular}

The rainfall at the Ankasa site is bimodal, occurring mainly in May-June and in SeptemberNovember. The mean annual rainfall is about 2,035 mm (Ameka, 2000). At the Asuboni and Pawnpawn sites the rainfall is also bimodal, occurring mainly in May-June and SeptemberOctober but with lower mean annual rainfall of about 1,560 $\mathrm{mm}$ and 1,174 $\mathrm{mm}$ in Asuboni and Pawnpawn sites, respectively (Ameka, 2000). Asuboni and Pawnpawn rivers are seasonal. High water occurs during the rainy season (May-June) and low water during the dry season (November-April). Asuboni river dries up from about February to March/April and Pawnpawn river is dry in January. Ankasa river, however, is perennial but shows distinct seasonal fluctuation of alternating periods of high flow in May-June and low flow between December and March.

The forest type at Ankasa site is wet evergreen (Hall \& Swaine, 1981) and it is known as the Ankasa Resource Reserve. Dry semi-deciduous forest type occurs at the Asuboni and Pawnpawn sites (Hall \& Swaine, 1981). The forest at Asuboni has been severely degraded by bush fires but that at Pawnpawn is a fairly intact (non-degraded) reserved forest called Boti Falls Forest Reserve. The catchment area for each river from the sample site was calculated and is shown in Table 3. Also shown are the proportions of the catchment area in forest reserves and outside forest reserves.

TABLE 3

Characteristics of the catchment areas of the Ankasa, Asuboni and Pawnpawn rivers

$\begin{array}{lccc}\text { River } & \text { Area } & \begin{array}{l}\text { Area inside } \\ \text { forest reserve } \\ \left(\mathrm{km}^{2}\right)\end{array} & \begin{array}{l}\text { Area outside } \\ \text { forest reserve } \\ \left(\mathrm{km}^{2}\right)\end{array} \\ \text { River Ankasa } & 89.4 & 81.1 & 8.3 \\ \text { River Asuboni } & 171.8 & 10.3 & 161.5 \\ \text { River Pawnpawn } & 35.0 & 35.0 & 0.0\end{array}$

\section{Results and discussion}

The results of the measurements and chemical analyses of the physico-chemical variables of Ankasa, Asuboni and Pawnpawn rivers at the sites where Podostemaceae occur are presented in Fig. 2-5. The range (minimum and maximum) values are also shown in Table 4. The habitat of L. bowlingii in the Asuboni river was dry in February-April during the study period, and that of T. trifaria in Pawnpawn river was dry in January. Water quality at the three sites did not differ very much except for total dissolved solids, electrical conductivity and nitrogen compounds (Fig. 2-5). Total dissolved solids and electrical conductivity were higher in Asuboni and Pawnpawn 
rivers than in Ankasa river. On the other hand, nitrogen compounds were higher in Ankasa river than in Asuboni and Pawnpawn rivers.

The study examined the water chemistry of the rivers harbouring the Podostemaceae (see Table 4 and Fig. 2-5). All the three rivers, Ankasa, Asuboni and Pawnpawn, had very low total suspended solids of 0-7 $\mathrm{mg} \mathrm{l}^{-1}$. A similar study in Japan reported suspended solids of $3 \mathrm{mg} / \mathrm{l}$ (Noro et al., 1994). It appeared that low total suspended solids in rivers suited the growth of Podostemaceae species as the attachment of seeds and seedlings to the substrata would not be disturbed by deposits of particles or silt on the surface of the substrata. Turbidity of the water was consequently low, between 2 and 13 NTU which allowed adequate illumina-tion of the submerged plants.

TABLE 4

The range (minimum and maximum) values of 14 chemical variables measured in Ankasa, Asuboni and Pawnpawn rivers. (For each variable, $N=24$ for Ankasa; $N=18$ for Asuboni; and $N=22$ for Pawnpawn)

$\begin{array}{lccc}\text { Parameter } & \text { Ankasa } & \text { Asuboni } & \text { Pawnpawn } \\ & & & \\ \text { Ammonia-nitrogen }\left(\mathrm{mg} \mathrm{l}^{-1}\right) & 0.07-0.91 & 0.11-0.38 & 0.14-0.39 \\ \text { Calcium }\left(\mathrm{mg} \mathrm{l}^{-1}\right) & 2.20-15.00 & 4.00-16.00 & 4.00-12.00 \\ \text { Chloride }\left(\mathrm{mg} \mathrm{l}^{-1}\right) & 12.50-30.00 & 10.00-38.00 & 6.80-35.00 \\ \text { Electrical conductivity }\left(\mu \mathrm{S} \mathrm{cm}^{-1}\right) & 26.40-52.40 & 46.40-129.80 & 43.90-138.00 \\ \text { Magnesium }\left(\mathrm{mg} \mathrm{l}^{-1}\right) & 0.49-5.35 & 1.46-9.72 & 0.45-8.51 \\ \text { Nitrate-nitrogen }\left(\mathrm{mg} \mathrm{l}^{-1}\right) & 0.14-0.35 & 0.11-0.54 & 0.13-0.61 \\ p \mathrm{H} & 6.65-7.20 & 6.80-7.30 & 6.76-7.29 \\ \text { Phosphate }\left(\mathrm{mg} \mathrm{l}^{-1}\right) & 0.03-0.09 & 0.01-0.33 & 0.02-0.08 \\ \text { Silicate }\left(\mathrm{mg} \mathrm{l}^{-1}\right) & 0.00-15.21 & 0.00-21.33 & 8.12-21.37 \\ \text { Sulphate }\left(\mathrm{mg} \mathrm{l}^{-1}\right) & 1.52-7.20 & 4.06-8.90 & 3.18-20.75 \\ \text { Total dissolved solids }\left(\mathrm{mg} \mathrm{l}^{-1}\right) & 21.30-38.00 & 30.00-88.20 & 32.60-89.50 \\ \text { Total hardness }\left(\mathrm{mg} \mathrm{l}^{-1}\right) & 10.00-30.00 & 10.00-55.00 & 10.00-55.00 \\ \text { Total suspended solids }\left(\mathrm{mg} \mathrm{l}^{-1}\right) & 0.00-2.00 & 0.00-7.00 & 0.00-2.00 \\ \quad \text { Turbidity }(\mathrm{NTU}) & 2.00-12.00 & 3.00-11.00 & 2.90-13.00\end{array}$



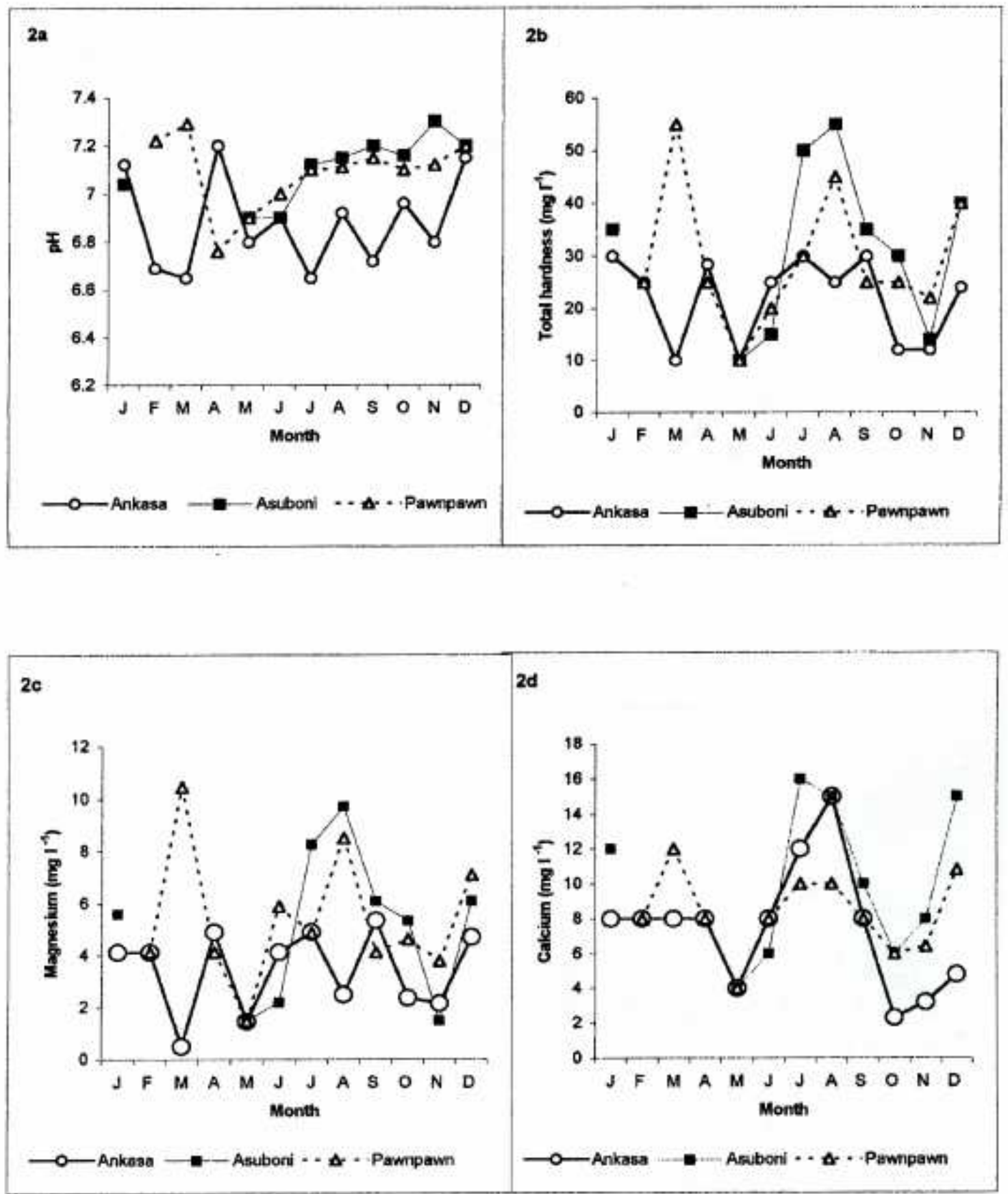

Fig. 2. Seasonal changes in $p \mathrm{H}$, total hardness and cations (magnesium and calcium) in Ankasa, Asuboni and Pawnpawn rivers, 1997 and 1998 

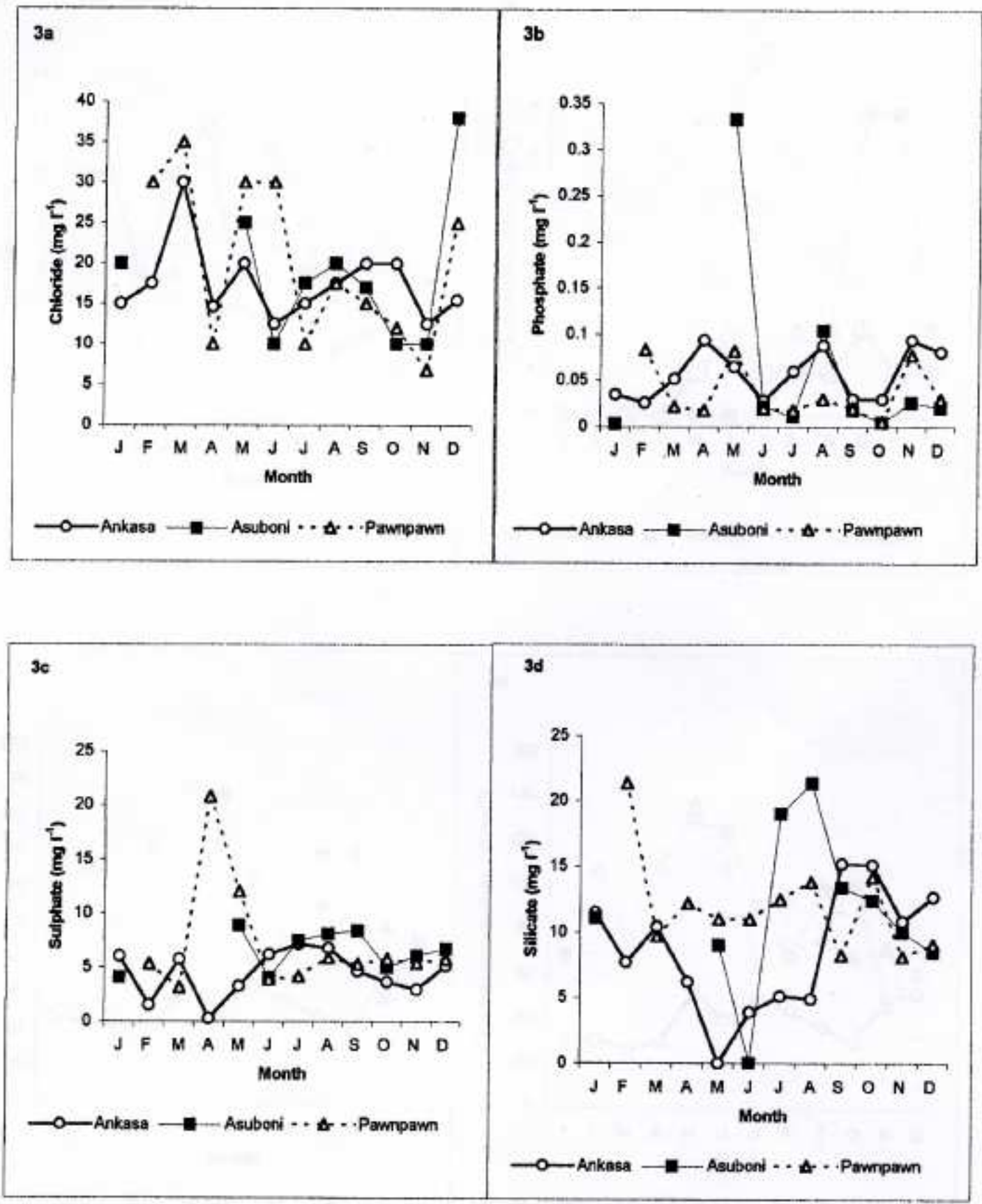

Fig. 3. Seasonal changes in major anions (chloride, phosphate, sulphate and silicate) in Ankasa, Asuboni and Pawnpawn rivers, 19971998 

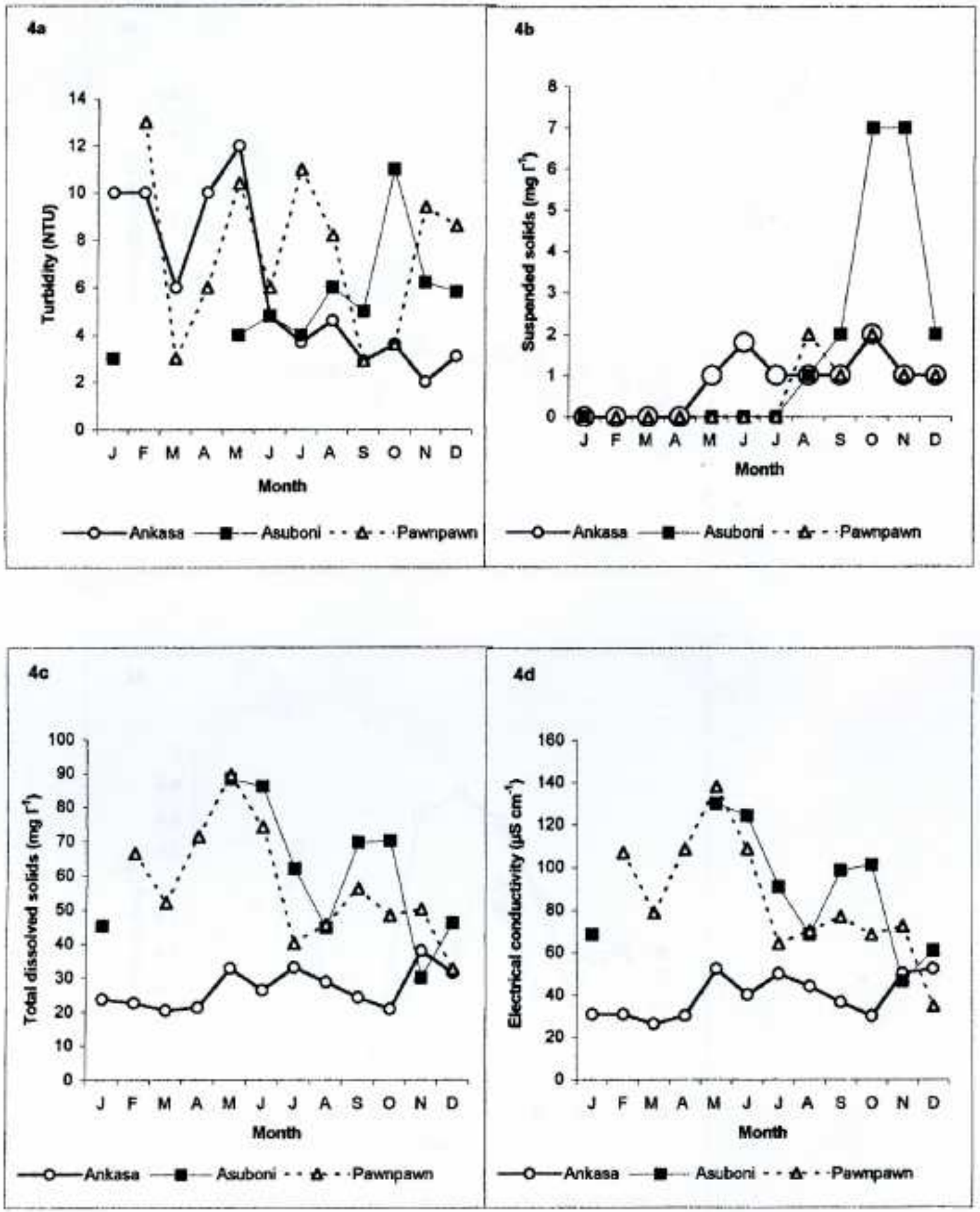

Fig. 4. Seasonal variation in turbidity, suspended solids, total dissolved solids and electrical conductivity in Ankasa, Asuboni and Pawnpawn rivers, 1997 and 1998 

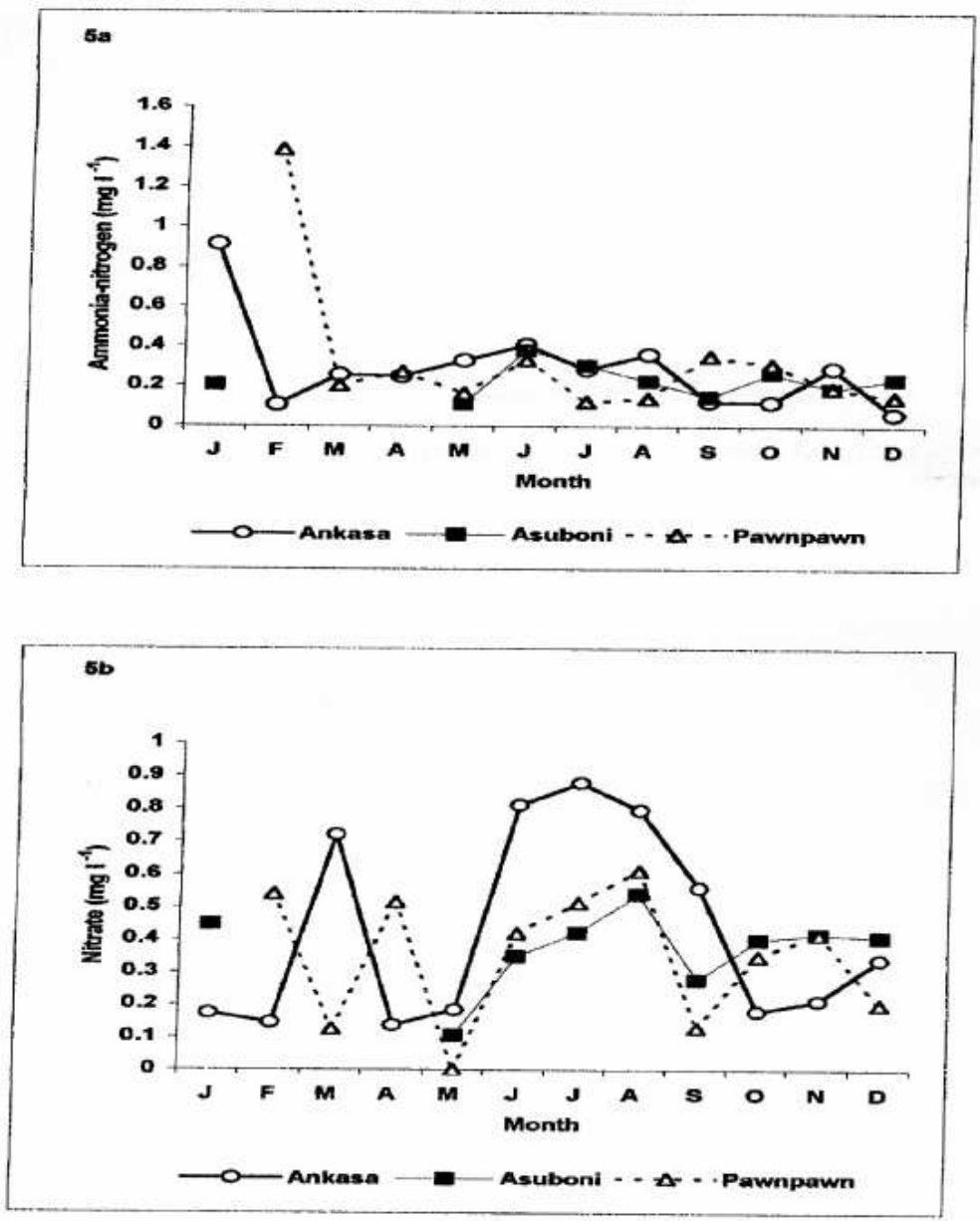

Fig. 5. Seasonal variation in ammonia-nitrogen and nitrate-nitrogen in Ankasa, Asuboni and Pawnpawn rivers, 1997 and 1998

The $p \mathrm{H}$ range of 6.7-7.3 is similar to the range recorded for the majority of West African rivers (River Niger, $p \mathrm{H} \mathrm{7.1-7.8;} \mathrm{River} \mathrm{White} \mathrm{Volta,} p \mathrm{H}$ 6.7; River Black Volta, $p \mathrm{H}$ 7.8; River Senegal, $p \mathrm{H} \mathrm{7.4;} \mathrm{River} \mathrm{Bandama,} p \mathrm{H}$ 6.9; River Logone-Shari, $p \mathrm{H}$ 7.5; River Oshum, $p \mathrm{H}$ 7.28.0) as reported by John (1986). Similarly, the Kaminokawa river in Japan in which Hydrobryum japonicum Imamura was growing had $p \mathrm{H}$ range of 6.8-7.0 (Noro et al., 1994), and Mexican rivers in which Podostemaceae were growing had $p \mathrm{H}$ range of 7.1-9.1 (Quiroz et al., 1997).

There were detectable levels of all the nutrients measured. Comparing with a relevant study by Quiroz et al. (1997) in Mexico, the present values are suited to the growth of Podostemaceae. For example, calcium levels in the three rivers ranged from 2.2 to $16.0 \mathrm{mg} \mathrm{l-}^{-1}$, and the levels in the 28 rivers in Mexico ranged from 0.1 to $9.9 \mathrm{mg} \mathrm{l}^{-1}$. Other corresponding pairs of values are $0.5-9.7$ $\mathrm{mg} \mathrm{l}^{-1}$ and $0.1-3.2 \mathrm{mg} \mathrm{1-}$, respectively, for magnesium; $0.01-0.30 \mathrm{mg} \mathrm{l}^{-1}$ and $0.1-0.6 \mathrm{mg} \mathrm{1-}{ }^{1}$, respectively, for phosphate; and $0.1-0.9 \mathrm{mg} \mathrm{l}^{-1}$ and $0.1-1.9 \mathrm{mg} \mathrm{l}^{-1}$, respectively, for nitratenitrogen.

An interesting observation was that the maximum levels of nitrate-nitrogen of $0.0,0.5$ and 0.6 mg 1-1 for Ankasa, Asuboni and Pawnpawn rivers, respectively, and the corresponding values of $0.9,0.4$ and $0.4 \mathrm{mg} \mathrm{l}^{-1}$ of ammonia-nitrogen (Table 4) seem to relate directly to the proportions of the catchment areas occupied by forest reserves, i.e. $81.1,10.3$ and $35.0 \mathrm{~km}^{2}$, respectively, for Ankasa, Asuboni and Pawnpawn rivers (Table 3). The greater the area of forest reserve, the 
greater the amount of litter received by the river and the greater the amount of plant decomposition products added to the water. However, the amount of litter did not reach levels which would foul the water.

The geology of the parent material affects the availability of substances for export to rivers. The riverbeds in Asuboni and Pawnpawn rivers are of sandstone rock. Sandstone-derived soils are generally relatively nutrient poor and acidic and this was reflected in river water chemistry of Asuboni and Pawnpawn rivers. Quartz vein rocks are primarily made up of silica and, therefore, rivers with such bedrock, as is the case at Ankasa site, should be nutrient poor. Thus, many of the physico-chemical parameters measured did not vary much between the three river sites.

Forest cover and rainfall amounts affect water chemistry. Ankasa site is located in high rainfall evergreen forest where rivers are usually perennial. The other sites, Asuboni and Pawnpawn, occur in low rainfall dry semi-deciduous forest zones. Here, the rivers are usually seasonal. Under high rainfall and evergreen forest cover conditions, the river tends to have high nitrate and ammonium concentrations (Table 4). This may reflect decomposition of litter-fall directly into the river from the surrounding trees and surface runoff. In low rainfall areas most water entering the rivers is by slow, deep seepage from the soil profile rather than surface flow, with the result that it is high in total dissolved solids and cations. River catchments with a high proportion of closed-canopy forest (as at Ankasa) compared with open types (as at Asuboni and Pawnpawn) have lower dissolved solids concentration (Table 4).

\section{References}

Ameka G. K. (2000). The Biology, Taxonomy and Ecology of the Podostemaceae in Ghana. (PhD Thesis.) Department of Botany, University of Ghana, Legon.

Ameka G. K., Pfeifer E. and Rutishauser R. (2002). Developmental morphology of Saxicolella amicorum and $S$. submersa (Podostemaceae: Podostemoideae) from Ghana. Bot. J. 319: 255-273.

Anonymous (1973). Ghana Survey Maps. The Survey Department, Ministry of Lands and Mineral Resources of Ghana, Accra.

APHA-AWWA-WPCF (1989). Standard Methods for the Examination of Water and Wastewater, 17th edn. Port City Press, Baltimore, USA.

Cook C. D. K. (1996). Aquatic Plant Book, 2nd revised edn. SPB Academic Publishing, The Hague.

Cross Bell D. (1990). Biomonitoring the effect of rubber factory effluent on hill stream in Kanya Kumari district. Geobios 17: 220-222.

FAO (1975). Manual of Methods in Aquatic Environment Research. Part I - Methods for Detection, Measuring and Monitoring of Water Pollution. FIRI/T137, Rome.

Gessner F. and Hammer L. (1962). Ökologisch-physiologische Untersuchungen an den Podostemonaceen des Caroni. Int. Revue ges. Hydrobiol. 47: 497-541.

Grubert M. (1975). Oekologie extrem adaptierter Blütenplanzen Wasserfälle. Biologie Zeit 5: 19-26.

Hall J. B. and Swaine M. D. (1981). Distribution and Ecology of Vascular Plants in a Tropical Rain Forest. W. Junk, The Hague.

John D. M. (1986). The inland waters of tropical West Africa. An introduction and botanical review. Ergebn. Limnol. 23: 1-222.

Kadono Y. and Usui N. (1995). Cladopus austro-osumiensis (Podostemaceae), a new rheophyte from Japan. Acta phytotax. geobot. 46(2): 131-135.

Mackereth F. J. H., Heron J. and Talling J. R. (1978). Water Analysis. F.B.A. No. 36.

Noro T., Suzuki H. and Kanayama T. (1994). Water Quality at the Habitat of Hydrobryum japonicum Imamura (Podostemaceae) in Japan. J. Jpn. Bot. 69: 167-175.

Novelo R. A. and Philbrick C. T. (1997). Taxonomy of Mexican Podostemaceae. Aquat. Bot. 57: 275-303.

Philbrick C. T. and Crow G. E. (1983). Distribution of Podostemum ceratophyllum Michx. (Podostemaceae). Rhodora 85: 325-341.

Philbrick C. T. and Novelo R. A. (1995). New World Podostemaceae: Ecological and evolutionary enigmas. Brittonia 47: 210-222.

Philbrick C. T. and Novelo R. A. (1997). Ovule number, seed number and seed size in Mexican and North American species of Podostemaceae. Aquat. Bot. 57: 183-200.

Quiroz, F. A., Novelo R. A. and Philbrick C. T. (1997). Water chemistry and the distribution of Mexican Podostemaceae: a preliminary evaluation. Aquat. Bot. 57: 201-212. 
Sioli H. (1986). Tropical continental aquatic habitats. In Conservation Biology, (M. Soule, ed.). Sinauer Associates, Sunderland, Ma.

van Steenis C. G. G. J. (1981). Rheophytes of the world. Sijthoff and Noordhoff, Alphen aan den Rijn. 